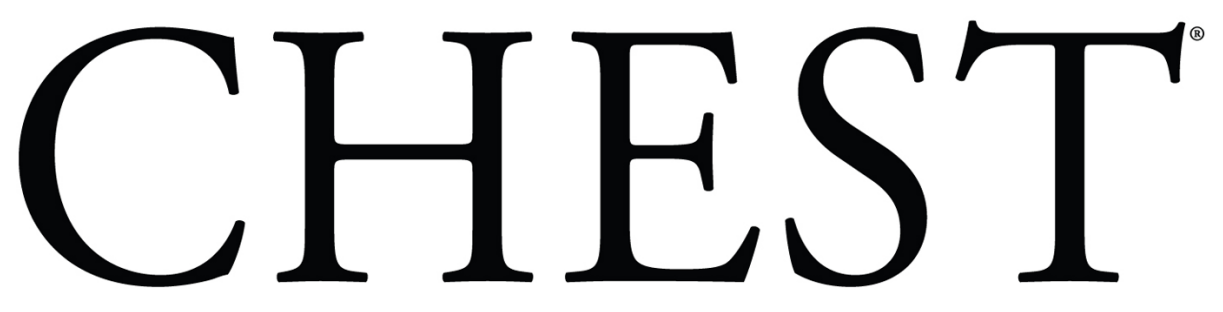

Official publication of the American C ollege of Chest Physicians Criteria To Identify Early Ventilątor-Associated Pneumonia in Brain Injury

Paolo Pelosi, Alessandra Barassi, Paolo Severgnini, Barbara Gomiero, Sergio Finazzi, Giampaolo Merlini, GianVico Melzi d'Eril, Maurizio Chiaranda and Michael S. Niederman

Chest 2008;134;101-108; Prepublished online April 10, 2008; DOI 10.1378/chest.07-2546

The online version of this article, along with updated information and services can be found online on the World Wide Web at: http://chestjournal.chestpubs.org/content/134/1/101.full.html

Chest is the official journal of the American College of Chest Physicians. It has been published monthly since 1935.

Copyright2008by the American College of Chest Physicians, 3300 Dundee Road, Northbrook, IL 60062. All rights reserved. No part of this article or PDF may be reproduced or distributed without the prior written permission of the copyright holder.

(http://chestjournal.chestpubs.org/site/misc/reprints.xhtml) ISSN:0012-3692

A M E R I C A N C O L L E G E O F

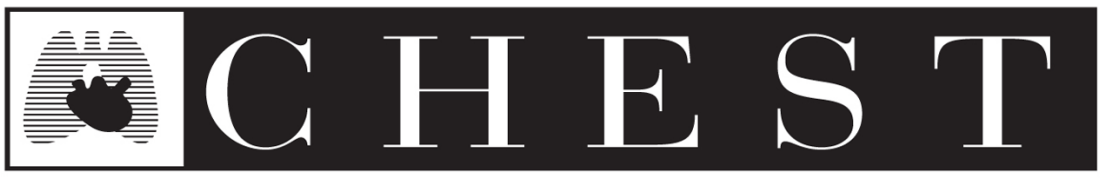
$\begin{array}{llllllllll}\mathrm{P} & \mathrm{H} & \mathrm{Y} & \mathrm{S} & \mathrm{I} & \mathrm{C} & \mathrm{I} & \mathrm{A} & \mathrm{N} & \mathrm{S}\end{array}$ 


\title{
Prognostic Role of Clinical and Laboratory Criteria To Identify Early Ventilator-Associated Pneumonia in Brain Injury*
}

\author{
Paolo Pelosi, MD; Alessandra Barassi, MD; Paolo Severgnini, MD; \\ Barbara Gomiero, MD; Sergio Finazzi, MD; Giampaolo Merlini, MD; \\ GianVico Melzi d'Eril, MD; Maurizio Chiaranda, MD; \\ and Michael S. Niederman, MD, FCCP
}

\begin{abstract}
Background: We investigated the role of the clinical pulmonary infection score (CPIS), serum levels of procalcitonin (PCT), C-reactive protein (CRP), and serum amyloid A (SAA) in the detection of patients with early ventilator-associated pneumonia (VAP).

Methods: Observational study in a university hospital. In 58 patients with severe brain injury receiving mechanical ventilation, CPIS, PCT, CRP and SAA were evaluated at ICU entry and at days 3 to 4 of hospital stay for VAP diagnosis (confirmed by endotracheal aspirate or BAL cultures).

Results: We found the following: (1) PCT at entry was increased in patients who later had early VAP develop (25 patients) compared to no VAP (median, $1.4 \mathrm{ng} / \mathrm{mL}$; 25-75 percentiles, 0.14-0.78; vs median, $0.2 \mathrm{ng} / \mathrm{mL}$; $25-75$ percentiles, $0.76-2.4, \mathrm{p}<0.001$; sensitivity, $76 \%$; and specificity, $75 \%$ ); (2) CPIS increased at the day of VAP diagnosis, compared to entry (median, $6.6 \pm 1.1 \mathrm{vs} 1.5 \pm 1.1$, p $<0.001$; sensitivity, $97 \%$; specificity, $100 \%$ ), while other serum inflammatory markers did not change; and (3) deterioration in oxygenation and changes in tracheal secretions were the main determinants of CPIS changes.

Conclusions: PCT may be a useful marker to predict which patients subsequently have early VAP. The CPIS could help as an early way to detect the patients with early VAP and who need further diagnostic testing.

(CHEST 2008; 134:101-108)
\end{abstract}

Key words: brain injury; clinical infection pulmonary score; C-reactive protein; procalcitonin; serum amyloid A; ventilatorassociated pneumonia

Abbreviations: CPIS = clinical pulmonary infection score; $\mathrm{CRP}=$ C-reactive protein; $\mathrm{FIO}_{2}=$ fraction of inspired oxygen; GCS = Glasgow coma scale; PCT = procalcitonin; SAA = serum amyloid A; VAP = ventilator-associated pneumonia

$\mathbf{P}$ atients with severe brain injury are at increased risk for ventilator-associated pneumonia (VAP), with a worsening of neurologic outcome, and increased ICU and hospital stay, mortality, and costs. ${ }^{1,2}$ Delays in the correct diagnosis and antibiotic administration have been found to increase hospital mortality $^{3,4}$; thus, rapid identification of VAP is required in an attempt to improve outcome.

The number of invasive diagnostic procedures should be minimized in severe brain-injured patients. ${ }^{5,6}$ The results of the quantitative cultures are not generally promptly available, and clinical signs of infection are poorly sensitive and specific. The diag-

nostic yield of these variables may increase when they are combined in the clinical infection pulmonary score (CPIS). ${ }^{7-9}$ Moreover, acute-phase inflammatory markers have been found to be poorly associated with the onset of VAP, while procalcitonin (PCT) has been reported to be a helpful parameter in the early diagnosis of VAP, ${ }^{10-12}$ and serum amyloid A (SAA) an appropriate marker of infections. ${ }^{13}$ In brain-injured patients, the serial measurement of PCT as a possible marker of the inflammatory process or as a diagnostic tool for VAP has not been reported.

In this study, we investigated a selected population of severe traumatic and nontraumatic brain-injured 
patients to evaluate the following: (1) the serial changes in acute-phase inflammatory markers (PCT, SAA, and CRP) in the early phase after trauma and their relation to clinical evolution; (2) and the role of clinical criteria, the CPIS, serum PCT, and SAA concentrations in the detection of patients with early VAP.

\section{Materials AND Methods}

\section{Patient Selection}

Sixty-seven brain-injured patients admitted to the ICU of the Servizio Anestesia B, Ospedale di Circolo e Fondazione Macchi, Insubria University, Varese, Italy were identified over a 1-year period. The study was approved by the Ethical Committee of the Hospital and performed in accordance with the precepts established by Helsinki Declaration. Inclusion criteria were as follows: (1) severe brain injury, defined as a Glasgow coma scale (GCS) score at hospital entry $\leq 8$, due to isolated brain trauma or spontaneous parenchymal hemorrhage; and (2) intubation and mechanical ventilation. Exclusion criteria were as follows: (1) age $<18$ years; (2) severe disease without any possibility of favorable outcome: brain death or cardiac arrest before ICU entry; (3) positive culture findings of tracheal aspirate or the BAL with evidence of pneumonia at the time of ICU admission; and (4) presence of any organ failure other than the brain. We excluded patients with respiratory failure due to pulmonary injury but allowed the use of ventilatory support for airway protection in the setting of severe neurologic injury.

Clinical treatment was performed according to general recommendations. All patients received antibiotic prophylaxis with ampicillin/sulbactam for the first 3 days of ICU entry.

\section{Clinical and Laboratory Variables}

Clinical Evaluation and CPIS: As shown in Table 1 CPIS calculation was made by modified original score as described by Pugin et al. ${ }^{7}$ We also computed a simplified CPIS not including the chest radiographic score (simplified CPIS).

${ }^{*}$ From Servizio di Anestesia e Rianimazione B (Drs. Pelosi, Severgnini, Gomiero, and Chiaranda), Dipartimento Ambiente Salute e Sicurezza, Università degli Studi dell'Insubria, Varese, Italy; Dipartimento di Medicina, Chirurgia e Odontoiatria (Drs. Barassi and Melzi d'Eril), Università degli Studi di Milano, Milano, Italy; Laboratorio di Analisi (Dr. Finazzi), Ospedale di Legnano, Legnano, Italy; Laboratorio di Biotecnologie (Dr. Merlini), IRCCS Policlinico S. Matteo, Dipartimento di Biochimica, Università degli Studi di Pavia, Pavia, Italy; and Department of Medicine (Dr. Niederman), Winthrop University Hospital, Mineola, NY.

This study was performed at the Ospedale di Circolo e Fondazione Macchi, Varese, Italy.

This study was not supported by any financial support, and all the authors declare disclosure of any personal or financial support or financial interest in the subject matter or any actual or potential conflict of interest.

Manuscript received November 28, 2007; revision accepted March 5, 2008.

Reproduction of this article is prohibited without written permission from the American College of Chest Physicians (www.chestjournal. org/misc/reprints.shtml).

Correspondence to: Paolo Pelosi, MD, Servizio di Anestesia B, Ospedale di Circolo e Fondazione Macchi, viale Borri 57, 21100, Varese, Italy; e-mail: ppelosi@hotmail.com

DOI: 10.1378/chest.07-2546
Table 1-The CPIS Used in the Study

\begin{tabular}{lr}
\hline \hline \multicolumn{1}{c}{ Components } & Points \\
\hline Temperature, ${ }^{\circ} \mathrm{C}$ & \\
$\geq 36.5$ and $\leq 38.4$ & 0 \\
$\geq 38.5$ and $\leq 38.9$ & 2 \\
$\geq 39.0$ and $\leq 36.0$ & \\
Blood leukocytes, $\mu \mathrm{L}$ & 0 \\
$\geq 4,000$ and $\leq 11,000$ & 1 \\
$<4,000$ and $>11,000$ & \\
Tracheal secretions & 1 \\
Few & 2 \\
Moderate & 1 \\
Large & \\
Purulent & 0 \\
Oxygenation PaO ${ }_{2}$ Fio ${ }_{2}$, mm Hg & 2 \\
$>240$ or presence of ARDS & \\
$\leq 240$ and absence of ARDS & 0 \\
Chest radiograph & 1 \\
$\quad$ No infiltrate & 2 \\
Patchy or diffuse infiltrate & \\
Localized infiltrate &
\end{tabular}

Acute-Phase Inflammatory Markers: PCT serum concentrations were determined using an immunoluminometric assay (LUMI test PCT; Brahms Diagnostic; Berlin, Germany). For this assay, the lower limit of detection is approximately $0.16 \mathrm{ng} / \mathrm{mL}$, and the standard curve ranges between $0.08 \mathrm{ng} / \mathrm{mL}$ and 500 $\mathrm{ng} / \mathrm{mL}$. The upper reference limit reported in the package insert for PCT was $0.5 \mu \mathrm{g} / \mathrm{L}$.

SAA serum concentrations were determined using a latexenhanced nephelometric immunoassay (N Latex SAA; Dade Behring; Marburn, Germany). For this assay, the lower limit of detection is $2.6 \mathrm{mg} / \mathrm{L}$, and the standard curve ranges between 3 $\mathrm{mg} / \mathrm{L}$ and $200 \mathrm{mg} / \mathrm{L}$. The upper reference limit reported in the package insert for SAA was $10.2 \mathrm{mg} / \mathrm{L}$.

CRP serum concentrations were determined using a immunoturbidimetric assay (CRP Latex; Olympus Diagnostica; Hamburg, Germany). For this assay, the lower limit of detection is $1.38 \mathrm{mg} / \mathrm{L}$, and the standard curve ranges between $5 \mathrm{mg} / \mathrm{L}$ and $170 \mathrm{mg} / \mathrm{L}$. The upper reference limit reported in the package insert for CRP was $5 \mathrm{mg} / \mathrm{L}$.

\section{VAP Definition}

The diagnosis of VAP required not only positive results of tracheal aspirate quantitative cultures $\left(\geq 10^{6} \mathrm{cfu} / \mathrm{mL}\right)$ or BAL quantitative cultures $\left(\geq 10^{4} \mathrm{cfu} / \mathrm{mL}\right)$ but also a positive chest radiograph and clinical features be present according to American Thoracic Society guidelines. ${ }^{14}$ The tracheal aspirate or BAL were performed as generally recommended. ${ }^{14-16}$ Severity of the bacterial infection was based on the American College of Chest Physicians and the Society of Critical Care Medicine Consensus Conference criteria. ${ }^{17}$ VAP patients with severe sepsis or septic shock were classified as severe VAP.

\section{Protocol for Sampling}

Clinical evaluation, CPIS, acute-phase inflammatory markers (PCT, CRP, SAA), and cultures including endotracheal aspirate or BAL, were performed in all the patients at ICU entry (at entry). Based on our standard pattern of practice, we estimate that the actual delay in time between injury (or arrival in emergency department) and initial sampling ranged between 5 to 
Table 2-Demographics, Clinical Data, and Outcome Data*

\begin{tabular}{|c|c|c|c|c|}
\hline Variables & $\begin{array}{c}\text { No Early } \\
\text { VAP }\end{array}$ & $\begin{array}{c}\text { Early VAP } \\
\text { Overall }\end{array}$ & $\begin{array}{l}\text { No Severe } \\
\text { Early VAP }\end{array}$ & $\begin{array}{c}\text { Severe } \\
\text { Early VAP }\end{array}$ \\
\hline Patients, No. & 33 & 25 & 12 & 13 \\
\hline Male/female gender, No. & $18 / 15$ & $17 / 8$ & $7 / 5$ & $10 / 3$ \\
\hline Age, yr & $48.5 \pm 16.8$ & $50.6 \pm 15.7$ & $54.8 \pm 20.0$ & $46.8 \pm 9.6$ \\
\hline Body mass index, $\mathrm{kg} / \mathrm{m}^{2}$ & $24.4 \pm 2.8$ & $25.1 \pm 2.6$ & $25.6 \pm 3.1$ & $24.6 \pm 2.0$ \\
\hline Simplified acute physiology II score & $37.0 \pm 10.1 \uparrow$ & $42.0 \pm 8.2$ & $39.8 \pm 8.6$ & $44.0 \pm 7.6$ \\
\hline Brain trauma/no trauma, No. & $14 / 19$ & $14 / 11$ & $5 / 7$ & $9 / 4$ \\
\hline GCS score at ICU entry & $5.5 \pm 1.5$ & $5.3 \pm 1.3$ & $5.3 \pm 1.4$ & $5.3 \pm 1.3$ \\
\hline GCS score at ICU discharge & $14.5 \pm 1.4_{+}^{+}$ & $10.0 \pm 2.9$ & $9.5 \pm 2.8$ & $10.6 \pm 3.1$ \\
\hline \multicolumn{5}{|l|}{ ICU stay, $\mathrm{d}$} \\
\hline Overall & $6.2 \pm 4.1_{+}^{+}$ & $25.5 \pm 17.3$ & $30.5 \pm 20.9$ & $20.5 \pm 11.9$ \\
\hline Survivors & $8.0 \pm 3.2+\frac{t}{+}$ & $29.1 \pm 17.3$ & $33.4 \pm 20.1$ & $23.8 \pm 12.3$ \\
\hline Twenty-eight-day mortality, $\%$ & 24 & 28 & 25 & 30 \\
\hline
\end{tabular}

*Data are presented as mean \pm SD unless otherwise indicated.

$\dagger p=0.048$ vs early VAP overall.

$+\mathrm{t}<0.001$ vs early VAP overall, no severe early VAP, and severe early VAP.
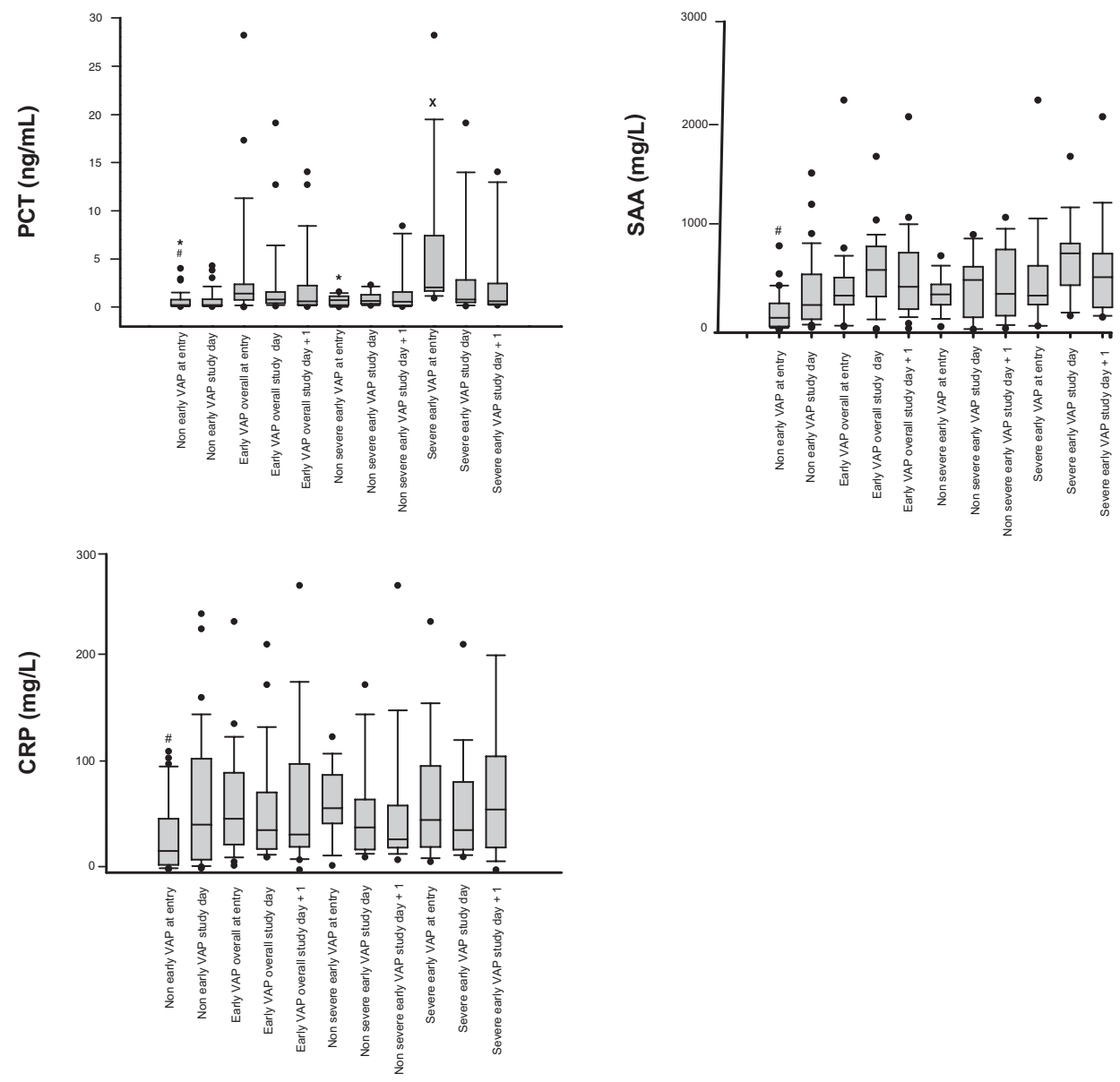

Figure 1. Top left panel: PCT (median, tenth, twenty-fifth, seventy-fifth, and ninetieth percentiles as vertical boxes with error bars and outlier data) at entry, study day, and study day +1 in no early VAP, early VAP overall, nonsevere early VAP, and severe early VAP. \#p $<0.001$ vs early VAP overall (at entry); ${ }^{*} p<0.001$ vs severe early VAP (at entry); ${ }^{x} p=0.021$ vs severe early VAP (study day); ${ }^{x} p=0.026$ vs severe early VAP (study day +1 ). Top right panel: SAA (median, tenth, twenty-fifth, seventy-fifth, and ninetieth percentiles as vertical boxes with error bars and outlier data) at entry, study day, and study day +1 , in no early VAP, early VAP overall, nonsevere early VAP, and severe early VAP. \#p $<0.001$ vs early VAP overall (at entry); $\# p=0.007$ vs no early VAP (study day). Bottom left panel: CRP (median, tenth, twenty-fifth, seventy-fifth, and ninetieth percentiles as vertical boxes with error bars and outliers data) at entry, study day, and study day +1 , in no early VAP, early VAP overall, nonsevere early VAP, and severe early VAP. $\# \mathrm{p}=0.004$ vs early VAP overall (at entry); \#p =0.034 vs no early VAP (study day). 
$15 \mathrm{~h}$, without any differences between the groups. Measurements and cultures were repeated after 3 to 4 days from entry (study day) and 1day after the study day (study day +1 ), if the temperature was $\geq 38^{\circ} \mathrm{C}$.

Thus, we were able to classify the patients in two groups: (1) patients without pneumonia at entry and at the study day (no early VAP group); and (2) patients without pneumonia at entry but who had VAP at the study day (early VAP group). We further divided the VAP group into patients with VAP associated with signs of severe sepsis or septic shock (severe early VAP group), and patients with VAP not associated with severe sepsis or septic shock (no severe early VAP group). Study days were $3.4 \pm 0.5$ days and $3.5 \pm 0.6$ days after entry in the early VAP group and no early VAP group, respectively.

\section{Statistical Methods}

Data are shown as mean \pm SD unless otherwise indicated. From previous studies, we computed that at least 15 patients with and without VAP were necessary to show a difference in PCT levels and CPIS with a power of $80 \%$ and an $\alpha$ error (at two tails) of 0.05. The SigmaStat statistical and SigmaPlot plotting packages (Systat Software; Chicago, IL) were used to analyze and plot the experimental data. Statistical analysis was performed by Student $t$ test and Mann-Whitney rank-sum test (when the normality test was violated); $\mathrm{p}<0.05$ was considered as significant.

\section{RESULTS}

\section{Clinical Characteristics and Acute-Phase}

Inflammatory Markers at Entry

We screened a total of 101 patients. We excluded 2 patients due to age $<18$ years, 3 patients due to extrahospital cardiac arrest or brain death, and 29 patients due to severe multiple trauma.

We included 67 patients with severe brain injury, but 9 patients were further excluded from the analysis due to positive culture finding of the endotracheal aspirate or BAL at entry. The remaining 58 brain-injured patients fulfilling the inclusion criteria were admitted into the study. The diagnosis of early VAP was established in 25 patients: 13 patients had Gram-negative bacilli, 6 patients had Gram-positive cocci, and polymicrobial growth was seen in 6 patients. Patients had no concomitant other infections. Table 2 shows demographic, clinical data, and outcome variables of the overall population. Patients who did have early VAP had an increased ICU stay, with worse GCS score at discharge. Acute-phase inflammatory markers are shown in Figure 1. PCT was increased on entry in early VAP vs no early VAP, and was higher on entry in severe vs nonsevere early VAP. SAA and CRP were higher at entry in early VAP vs no early VAP groups. None of the markers increased significantly from entry with the onset of VAP. In particular, the sensitivity and specificity of PCT and SAA at entry to predict patients with early VAP, independently from its severity, was $76 \%$ and $75.8 \%$, respectively (cut-off, $0.77 \mathrm{ng} / \mathrm{mL}$; area under the curve, 0.78) for PCT (Fig 2, top panel) and 84\% and $72.7 \%$, respectively (cut-off, $224 \mathrm{mg} / \mathrm{mL}$; area under the curve, 0.76) for SAA. More importantly, PCT but not CRP and SAA was significantly increased at entry and at study day in patients with severe VAP compared to nonsevere early VAP. The sensitivity and specificity of PCT at entry to predict patients with severe early VAP were $92.3 \%$ and $90.9 \%$, respectively (cut-off, $1.2 \mathrm{ng} / \mathrm{mL}$; area under the curve, 0.94) [Fig 2, bottom panel].

At entry, none of the variables other than oxygenation were different between those who did not have early VAP and the overall group that had early VAP
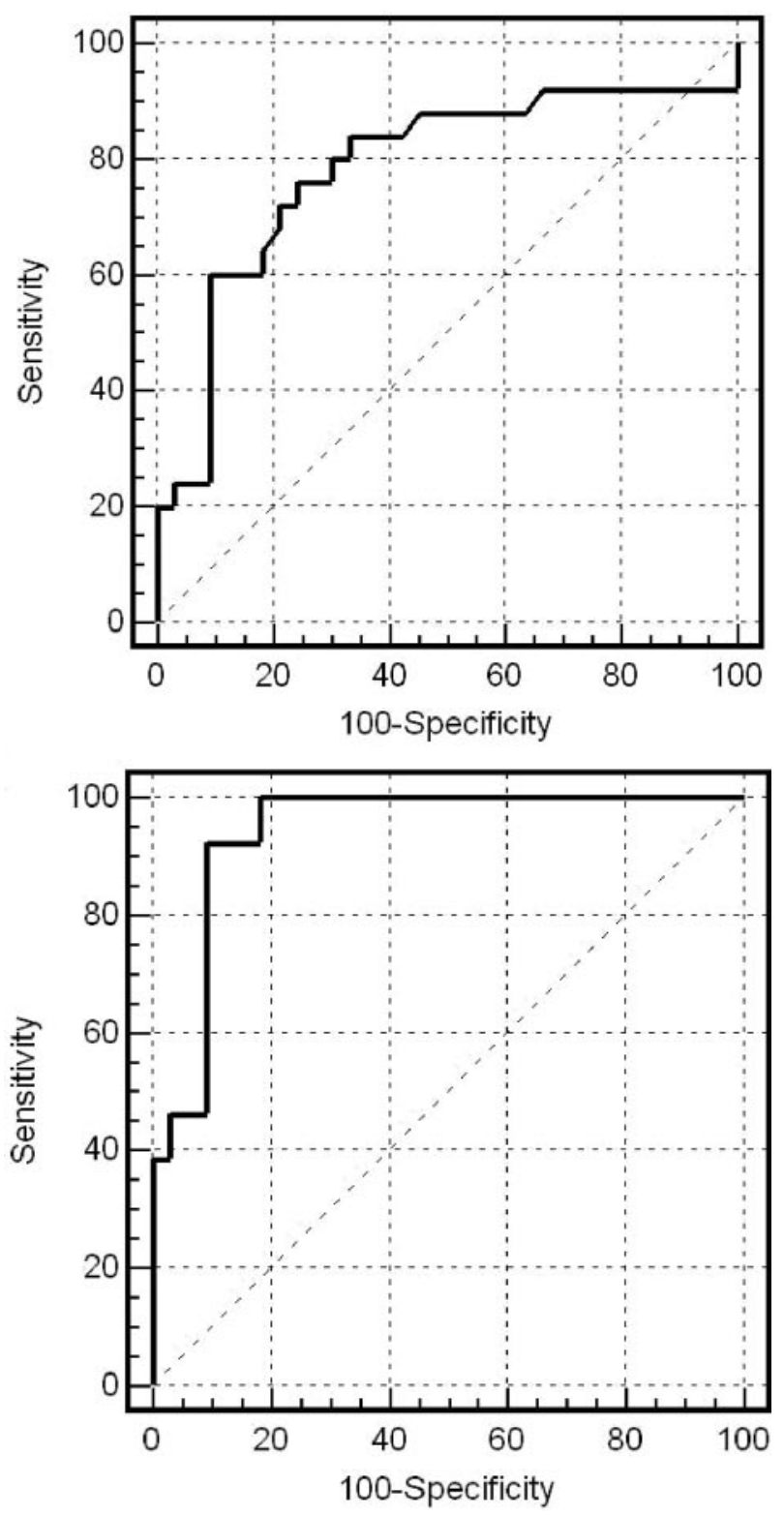

FIGURE 2. Top panel: Sensitivity and specificity expressed as receiver operating characteristic (ROC) curves of PCT at entry to predict early VAP. Bottom panel: Sensitivity and specificity expressed as receiver operating characteristic (ROC) curves of PCT at entry to predict severe early VAP. 
Table 3-Clinical Criteria*

\begin{tabular}{|c|c|c|c|c|}
\hline Variables & $\begin{array}{l}\text { No Early } \\
\text { VAP }\end{array}$ & $\begin{array}{l}\text { Early VAP } \\
\text { Overall }\end{array}$ & $\begin{array}{c}\text { No Severe Early } \\
\text { VAP }\end{array}$ & $\begin{array}{c}\text { Severe Early } \\
\text { VAP }\end{array}$ \\
\hline \multicolumn{5}{|l|}{ At ICU entry } \\
\hline Leukocytes, per $\mu \mathrm{L}$ & $12,862 \pm 6,574$ & $13,136 \pm 4,857$ & $13,110 \pm 4,968$ & $13,160 \pm 4,956$ \\
\hline Temperature, ${ }^{\circ} \mathrm{C}$ & $36.7 \pm 0.9$ & $37.1 \pm 0.7 \S$ & $37.1 \pm 0.5 \$$ & $37.2 \pm 0.8 \$$ \\
\hline Tracheal secretion & $0.1 \pm 0.3$ & $0.1 \pm 0.3+\frac{1}{+} \oint$ & $0.2 \pm 0.4_{+}^{+} \S$ & $0.1 \pm 0.3+\frac{+}{+} 8$ \\
\hline Oxygenation $\mathrm{PaO}_{2} / \mathrm{FIO}_{2}, \mathrm{~mm} \mathrm{Hg}$ & $404.9 \pm 100.3$ & $345.9 \pm 96.3+\$$ & 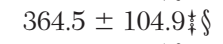 & $328.8 \pm 88.2+\$$ \\
\hline Radiographic score & $0.2 \pm 0.6$ & $0.2 \pm 0.7+\frac{+}{+} \oint$ & $0.2 \pm 0.6+\$ \frac{1}{8}$ & $0.3 \pm 0.8+\frac{\text { t }}{\oint}$ \\
\hline \multicolumn{5}{|l|}{ Study day } \\
\hline Leukocytes, per $\mu \mathrm{L}$ & $10,585 \pm 5,200$ & $11,821 \pm 4,106$ & $12,055 \pm 4,656$ & $11,605 \pm 3,706$ \\
\hline Temperature, ${ }^{\circ} \mathrm{C}$ & $36.8 \pm 1.0 \uparrow$ & $37.5 \pm 1.0$ & $37.5 \pm 1.1$ & $37.4 \pm 0.9$ \\
\hline Tracheal secretion & $0.2 \pm 0.4 \uparrow$ & $2.5 \pm 0.8$ & $2.2 \pm 1.0$ & $2.7 \pm 0.5$ \\
\hline Oxygenation $\mathrm{PaO}_{2} / \mathrm{FiO}_{2}, \mathrm{~mm} \mathrm{Hg}$ & $385.8 \pm 82.0 \nmid$ & $241.0 \pm 53.5$ & $275.8 \pm 51.9$ & $208.9 \pm 30.3$ \\
\hline Radiographic score & $0.1 \pm 0.5 \nmid$ & $1.5 \pm 0.7$ & $1.4 \pm 0.8$ & $1.7 \pm 0.5$ \\
\hline \multicolumn{5}{|l|}{ Study day +1} \\
\hline Leukocytes, per $\mu \mathrm{L}$ & & $11,162 \pm 3,383$ & $11,194 \pm 3,580$ & $11,132 \pm 3,338$ \\
\hline Temperature, ${ }^{\circ} \mathrm{C}$ & & $38.4 \pm 0.4$ & $38.5 \pm 0.4$ & $38.3 \pm 0.3$ \\
\hline Tracheal secretion & & $2.6 \pm 0.6$ & $2.4 \pm 1.0$ & $2.7 \pm 0.5$ \\
\hline Oxygenation $\mathrm{PaO}_{2} / \mathrm{FiO}_{2}, \mathrm{~mm} \mathrm{Hg}$ & & $251.7 \pm 50.7$ & $289.5 \pm 36.9$ & $234.0 \pm 32.8$ \\
\hline Radiographic score & & $1.6 \pm 0.7$ & $1.4 \pm 0.8$ & $1.7 \pm 0.5$ \\
\hline
\end{tabular}

*Data are presented as mean $\pm \mathrm{SD}$.

$\nmid \mathrm{p}<0.001$ vs early VAP overall, no severe early VAP, severe early VAP.

$+\mathrm{p}<0.001$ vs study day.

$\$ p<0.001$ vs study day +1 .

(Table 3). In Figure 3, at entry the CPIS and the simplified CPIS were comparable in all groups.

\section{Clinical Characteristics and Acute-Phase}

\section{Inflammatory Markers for Early VAP Diagnosis}

In early VAP group serial measurements of PCT, $\mathrm{CRP}$ and SAA were not significantly different at the study day and at study day +1 compared to entry (Fig 1). At study day, positive end-expiratory pressure was higher $\left(7.7 \pm 2.2 \mathrm{~cm} \mathrm{H}_{2} \mathrm{O}\right.$ vs $4.7 \pm 1.1 \mathrm{~cm} \mathrm{H}_{2} \mathrm{O}$, $\mathrm{p}<0.001)$ and compliance was lower $(62.0 \pm 11.3$ $\mathrm{mL} / \mathrm{cm} \mathrm{H}_{2} \mathrm{O}$ vs $\left.71.2 \pm 7.6 \mathrm{~mL} / \mathrm{cm} \mathrm{H}_{2} \mathrm{O}, \mathrm{p}<0.001\right)$ in overall early VAP as compared to no early VAP group.

In the overall early VAP group, among clinical criteria (excluding radiographic score), only tracheal secretions increased, while $\mathrm{PaO}_{2} /$ fraction of inspired oxygen $\left(\mathrm{FIO}_{2}\right)$ deteriorated at study day and at study day +1 compared to entry (Table 3 ). $\mathrm{PaO}_{2} / \mathrm{FIO}_{2}$ was lower in severe compared to non-severe early VAP at study day and study day +1 .

The total CPIS and the simplified CPIS markedly increased in the overall early VAP group at study day and study day +1 compared to entry (Fig 3 ). These data suggest that early VAP can be diagnosed in patients with a CPIS $>3$ or a simplified CPIS $>3$ with a sensitivity of $97.1 \%$ and $85.3 \%$ respectively and a specificity $100 \%$.

\section{DisCUSSION}

This is the first study investigating the role of PCT and the CPIS for early detection of patients with early VAP in the setting of brain injury. In severe brain-injured patients, the most frequent medical complication is respiratory dysfunction, with an increased mortality and worse neurologic outcome. ${ }^{18-22}$ In this study we investigated changes in CRP, ${ }^{23}$ SAA, ${ }^{24,25}$ PCT, and leukocytes. Serum concentrations of PCT have been reported to be markedly increased in a variety of clinical and experimental conditions that lead to systemic inflammation. ${ }^{26,27}$ In many of these studies, the concentrations of PCT reflected the severity of the systemic inflammation and were predictive of mortality. ${ }^{28}$

We observed that in brain-injured patients, an elevated PCT on ICU entry correlated with the subsequent development of early VAP. Patients with VAP had a higher initial PCT than those who did not, although most of the high initial PCT values occurred in patients who had severe VAP, but not in those with nonsevere VAP (Fig 1, top left panel). In addition, those who had VAP had no serial rise in PCT. These findings may mean that either patients with severe VAP had intense inflammation initially, as reflected by high PCT, 29,30 which predisposed to subsequent pneumonia, or that they had aspirated prior to arrival in the hospital and may already have had a pneumonia, although it was not able to be detected clinically by radiography or by other clinical criteria.

A previous study ${ }^{31}$ in brain-injured patients reported that serum PCT appeared to be correlated with the severity of traumatic brain injury and mortality. However, we did not find any significant correlation between the level of PCT and the sever- 

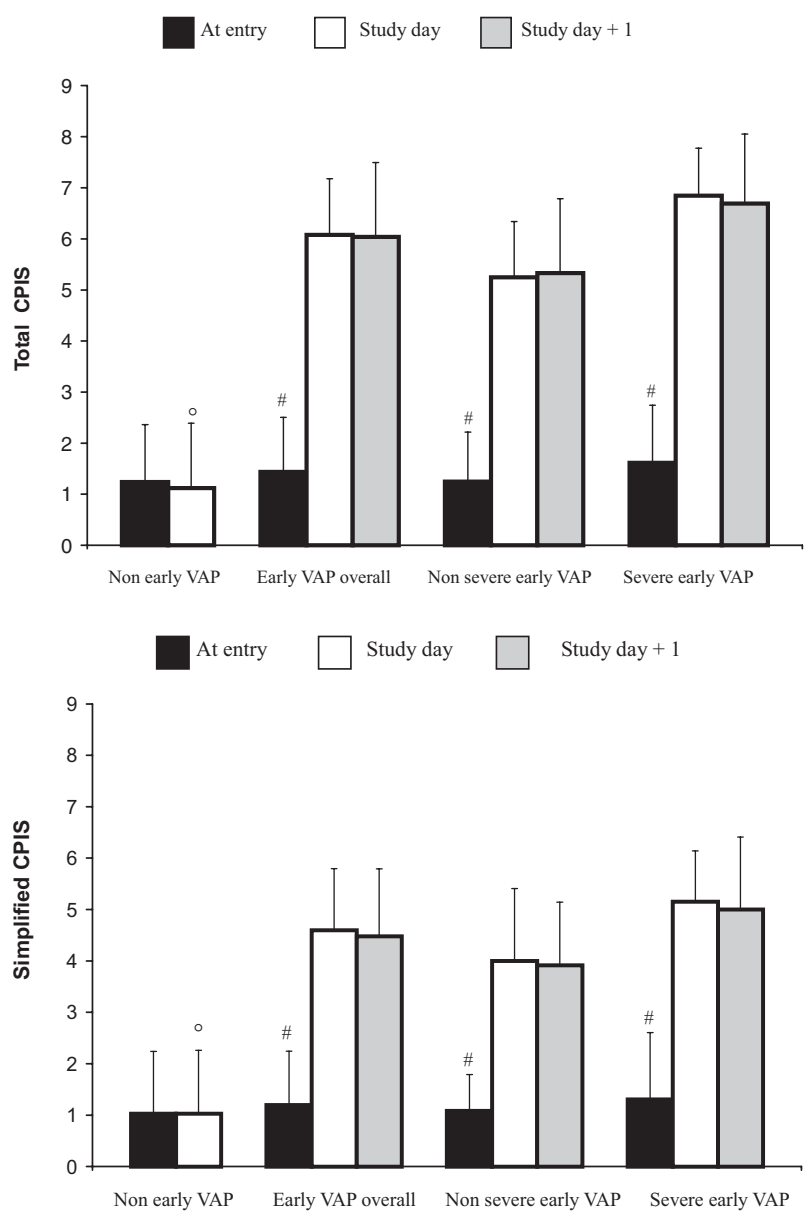

FIGURE 3. Top panel: Total CPIS (mean \pm SD) at entry, study day, and study day +1 , in no early VAP, early VAP overall, nonsevere early VAP, and severe early VAP. ${ }^{\circ} \mathrm{p}<0.001$ vs early VAP overall (study day), nonsevere early VAP (study day), severe early VAP (study day); \#p $<0.001$ vs study day and study day +1 . Bottom panel: Simplified CPIS (mean \pm SD) at entry, study day, and study day +1 , in no early VAP, early VAP overall, nonsevere early VAP, and severe early VAP. ${ }^{\circ} \mathrm{p}<0.001$ vs early VAP overall (study day), nonsevere early VAP (study day), severe early VAP (study day). $\# \mathrm{p}<0.001$ vs study day and study day +1 .

ity of the brain injury as defined by GCS score, unlike other authors, ${ }^{32}$ who reported an increase in serum PCT for patients with brain injury associated with extracranial injuries. This discrepancy can be attributed to the fact that we did not include patients with extracranial injuries in our study. The GCS score may not be directly related to the size of the brain lesion but rather to its anatomic location, and the size of the lesion may not be directly associated with the extent of the inflammatory response per se.

In our study, we found that none of the most common acute-phase inflammatory markers increased in patients who had early VAP. This finding is different from previous data reported in a general population of critically ill patients ${ }^{11}$ and after closed head injury, ${ }^{33}$ and may be explained by the maximal increase in PCT (Fig 1) in those patients destined to get severe early VAP.

Controversy, however, about the clinical diagnosis of VAP continues. ${ }^{34}$ The use of the CPIS to detect $\mathrm{VAP}^{7,8}$ has been found to be $100 \%$ specific and $93 \%$ sensitivity in a general population of critically ill patients, but not confirmed in studies. ${ }^{35-37}$ One study ${ }^{38}$ in trauma patients, performed on a single-day examination of bacteriologic and clinical parameters, suggested that the CPIS cannot differentiate VAP. Among the different parameters included in the CPIS, we found that the variations in secretions and oxygenation were the most important features. ${ }^{8,9,39}$ We found that a simplified CPIS $>3$ was useful to predict the patients with early VAP as confirmed by invasive techniques. The threshold of the CPIS for VAP diagnosis was lower than that reported previously $(>6)$ because we selected a group of patients without any previous pulmonary alteration or infection before VAP. Thus, the use of the CPIS could be a useful tool to reduce the number of invasive diagnostic procedures, potentially harmful in braininjured patients, ${ }^{6}$ restricting the use of these techniques to those with an elevated CPIS.

Our study suffers some potential limitations: (1) patients with positive microbiological culture findings at entry were excluded; thus, our results would be less consistent in patients with lung parenchyma infection at entry; (2) some of the patients with negative culture findings could have had infection on entry, overestimating the role of PCT to predict occurrence of early VAP40; (3) antibiotic prophylaxis may have impacted the value of PCT measurements and the frequency of pneumonia; (4) CPIS and serum markers were measured by protocol at days 3 to 4 in all patients, and thus it is possible that VAP occurred 1 or 2 days earlier; thus. a persistently elevated PCT level may reflect inappropriate therapy, as previously suggested by Luyt et al ${ }^{12}$; (5) it is possible that PCT values were increased because of trauma itself; and (6) the small sample size studied.

Our results can have potential clinical implications. First, patients with increased PCT were at increased risk for subsequent severe early VAP. Second, we did not find any usefulness to specific acute-phase inflammatory markers at days 3 to 4 to detect patients when they had pneumonia. The use of the CPIS can be useful to define pneumonia patients. mainly from the oxygenation deterioration and the evaluation of tracheal secretions. We suggest that this score be monitored in order to rapidly detect patients with early VAP and to reduce diagnostic procedures in severe brain-injured patients, 
limiting them only to patients with high CPIS values at the time they demonstrate signs of infection.

\section{REFERENCES}

1 Rincon-Ferrari MD, Flores-Cordero JM, Leal-Noval SR, et al. Impact of ventilator-associated pneumonia in patients with severe head injury. J Trauma 2004; 57:1234-1240

2 Kallel H, Chelly H, Bahloul M, et al. The effect of ventilatorassociated pneumonia on the prognosis of head trauma patients. J Trauma 2005; 59:705-710

3 Ewig S, Torres A, El-Ebiary M, et al. Bacterial colonization patterns in mechanically ventilated patients with traumatic and medical head injury: incidence, risk factors, and association with ventilator-associated pneumonia. Am J Respir Crit Care Med 1999; 159:188-198

4 Dupont H, Mentec H, Sollet JP, et al. Impact of appropriateness of initial antibiotic therapy on the outcome of ventilator-associated pneumonia. Intensive Care Med 2001; 27:355-362

5 Chastre J, Fagon JY, Bornet-Lecso M, et al. Evaluation of bronchoscopic techniques for the diagnosis of nosocomial pneumonia. Am J Respir Crit Care Med 1995; 152:231-240

6 Kerwin AJ, Croce MA, Timmons SD, et al. Effects of fiberoptic bronchoscopy on intracranial pressure in patients with brain injury: a prospective clinical study. J Trauma 2000; 48:878-882; discussion 882-883

7 Pugin J, Auckenthaler R, Mili N, et al. Diagnosis of ventilatorassociated pneumonia by bacteriologic analysis of bronchoscopic and nonbronchoscopic "blind" bronchoalveolar lavage. Am Rev Respir Dis 1991; 143:1121-1129

8 Luna CM, Blanzaco D, Niederman MS, et al. Resolution of ventilator-associated pneumonia: prospective evaluation of the clinical pulmonary infection score as an early clinical predictor of outcome. Crit Care Med 2003; 31:676-682

9 Singh N, Rogers P, Atwood CW, et al. Short-course empiric antibiotic therapy for patients with pulmonary infiltrates in the intensive care unit: a proposed solution for indiscriminate antibiotic prescription. Am J Respir Crit Care Med 2000; 162:505-511

10 Christ-Crain M, Jaccard-Stolz D, Bingisser R, et al. Effect of procalcitonin-guided treatment on antibiotic use and outcome in lower respiratory tract infections: cluster-randomised, singleblinded intervention trial. Lancet 2004; 363:600-607

11 Duflo F, Debon R, Monneret G, et al. Alveolar and serum procalcitonin: diagnostic and prognostic value in ventilatorassociated pneumonia. Anesthesiology 2002; 96:74-79

12 Luyt CE, Guerin V, Combes A, et al. Procalcitonin kinetics as a prognostic marker of ventilator-associated pneumonia. Am J Respir Crit Care Med 2005; 171:48-53

13 Malle E, De Beer FC. Human serum amyloid A (SAA) protein: a prominent acute-phase reactant for clinical practice. Eur J Clin Invest 1996; 26:427-435

14 American Thoracic Society and Infectious Disease Society of America. Guidelines for the management of adults with hospitalacquired, ventilator-associated, and healthcare-associated pneumonia. Am J Respir Crit Care Med 2005; 171:388-416

15 Luna CM, Vujacich P, Niederman MS, et al. Impact of BAL data on the therapy and outcome of ventilator-associated pneumonia. Chest 1997; 111:676-685

16 Fagon JY, Chastre J, Wolff M, et al. Invasive and noninvasive strategies for management of suspected ventilator-associated pneumonia: a randomized trial. Ann Intern Med 2000; 132: 621-630

17 Bone RC, Sprung CL, Sibbald WJ. Definitions for sepsis and organ failure. Crit Care Med 1992; 20:724-726
18 Holland MC, Mackersie RC, Morabito D, et al. The development of acute lung injury is associated with worse neurologic outcome in patients with severe traumatic brain injury. J Trauma 2003; 55:106-111

19 North JB, Jennett S. Abnormal breathing patterns associated with acute brain damage. Arch Neurol 1974; 31:338-344

20 Contant CF, Valadka AB, Gopinath SP, et al. Adult respiratory distress syndrome: a complication of induced hypertension after severe head injury. J Neurosurg 2001; 95:560-568

21 Marion DW, Penrod LE, Kelsey SF, et al. Treatment of traumatic brain injury with moderate hypothermia. N Engl J Med 1997; 336:540-546

22 Drakulovic MB, Torres A, Bauer TT, et al. Supine body position as a risk factor for nosocomial pneumonia in mechanically ventilated patients: a randomised trial. Lancet 1999; 354:1851-1858

23 Castell JV, Andus T, Kunz T, et al. Interleukin-6: the major regulator of acute-phase protein synthesis in man and rat. Ann N Y Acad Sci 1989; 557:87-101

24 Strachan AF, Brandt WF, Woo P, et al. Human serum amyloid A protein: the assignment of six major isoforms to three published gene sequence and evidence for two genetic loci. J Biol Chem 1989; 264:18368-18373

25 Sipe D. The acute-phase response in the pathogenesis of inflammatory disease: prospects pharmacotherapy. Clin Immunother 1995; 3:297-307

26 Reinhart K, Karzai W, Meisner M. Procalcitonin as a marker of the systemic inflammatory response to infection. Intensive Care Med 2000; 26:1193-1200

27 Becker KL, Nylen ES, White JC, et al. Clinical review 167: procalcitonin and the calcitonin gene family of peptides in inflammation, infection, and sepsis: a journey from calcitonin back to its precursors. J Clin Endocrinol Metab 2004; 89: $1512-1525$

28 Oberhoffer M, Vogelsang H, Russwurm S, et al. Outcome prediction by traditional and new markers of inflammation in patients with sepsis. Clin Chem Lab Med 1999; 37:363-368; erratum in: Clin Chem Lab Med 1999; 37:697

29 Wagner KE, Martinez JM, Vath SD, et al. Early immunoneutralization of calcitonin precursors attenuates the adverse physiologic response to sepsis in pigs. Crit Care Med 2002; 30:2313-2321

30 Nylen ES, Whang KT, Snider RH Jr, et al. Mortality is increased by procalcitonin and decreased by an antiserum reactive to procalcitonin in experimental sepsis. Crit Care Med 1998; 26:1001-1006

31 Oconnor E, Venkatesh B, Mashongonyika C, et al. Serum procalcitonin and C-reactive protein as markers of sepsis and outcome in patients with neurotrauma and subarachnoid haemorrhage. Anaesth Intensive Care 2004; 32:465-470

32 Sauerland S, Hensler T, Bouillon B, et al. Plasma levels of procalcitonin and neopterin in multiple trauma patients with or without brain injury. J Neurotrauma 2003; 20:953-960

33 Pusch F, Wildling E, Freitag $\mathrm{H}$, et al. Procalcitonin as a diagnostic marker in patients with aspiration after closed head injury. Wien Klin Wochenschr 2001; 113:676-680

34 Torres A, Ewig S. Diagnosing ventilator-associated pneumonia. N Engl J Med 2004; 350:433-435

35 Luyt CE, Chastre J, Fagon JY. Value of the clinical pulmonary infection score for the identification and management of ventilator-associated pneumonia. Intensive Care Med 2004; 30:844-852

36 Veinstein A, Brun-Buisson C, Derrode N, et al. Validation of an algorithm based on direct examination of specimens in suspected ventilator-associated pneumonia. Intensive Care Med 2006; 32:676-683

37 Seligman R, Meisner M, Lisboa TC, et al. Decreases in 
procalcitonin and C-reactive protein are strong predictors of survival in ventilator-associated pneumonia. Crit Care 2006; 10:R125

38 Croce MA, Swanson JM, Magnotti LJ, et al. The futility of the clinical pulmonary score in trauma patients. J Trauma 2006; 60:523-527
39 Gibot S, Cravoisy A, Levy B, et al. Soluble triggering receptor expressed on myeloid cells and the diagnosis of pneumonia. N Engl J Med 2004; 350:451-458

40 Fabregas N, Ewig S, Torres A, et al. Clinical diagnosis of VAP revisited: comparative validation using immediate post-mortem lung biopsies. Thorax 1999; 54:867-873 


\section{Prognostic Role of Clinical and Laboratory Criteria To Idenztify Early Ventilator-Associated Pneumonia in Brain Injury}

Paolo Pelosi, Alessandra Barassi, Paolo Severgnini, Barbara Gomiero, Sergio Finazzi, Giampaolo Merlini, GianVico Melzi d'Eril, Maurizio Chiaranda and Michael S. Niederman

Chest 2008;134; 101-108; Prepublished online April 10, 2008;

DOI 10.1378/chest.07-2546

\section{This information is current as of April 25, 2012}

\section{Updated Information \& Services}

Updated Information and services can be found at:

http://chestjournal.chestpubs.org/content/134/1/101.full.html

\section{References}

This article cites 40 articles, 11 of which can be accessed free at:

http://chestjournal.chestpubs.org/content/134/1/101.full.html\#ref-list-1

\section{Cited Bys}

This article has been cited by 3 HighWire-hosted articles:

http://chestjournal.chestpubs.org/content/134/1/101.full.html\#related-urls

\section{Permissions \& Licensing}

Information about reproducing this article in parts (figures, tables) or in its entirety can be found online at:

http://www.chestpubs.org/site/misc/reprints.xhtml

\section{Reprints}

Information about ordering reprints can be found online:

http://www.chestpubs.org/site/misc/reprints.xhtml

\section{Citation Alerts}

Receive free e-mail alerts when new articles cite this article. To sign up, select the "Services" link to the right of the online article.

\section{Images in PowerPoint format}

Figures that appear in CHEST articles can be downloaded for teaching purposes in PowerPoint slide format. See any online figure for directions.

\section{A M E R I C A N C O L L E G E O F}

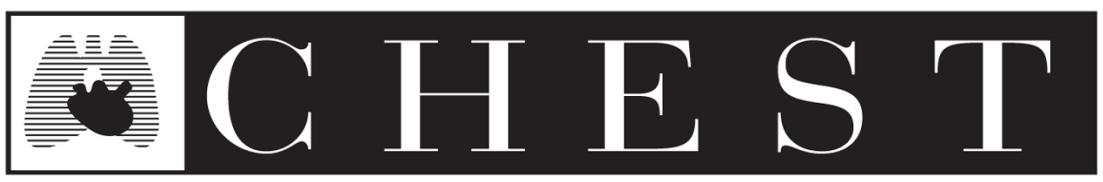
$\mathrm{P}$

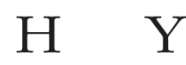
S I
C I
A $\quad \mathrm{N} \quad \mathrm{S}^{\circledR}$ 